University of Rhode Island

DigitalCommons@URI

Symposium: "Tales of North and South in Antebellum America: A Complicated Web"

TMD Symposiums and Conferences

9-28-2019

\title{
2. Patches of Resistance on the Badges of Enslavement
}

Katie Knowles

Colorado State University

Follow this and additional works at: https://digitalcommons.uri.edu/tmd-symposium-2019

\section{Recommended Citation}

Knowles, Katie, "2. Patches of Resistance on the Badges of Enslavement" (2019). Symposium: "Tales of North and South in Antebellum America: A Complicated Web". Paper 3.

https://digitalcommons.uri.edu/tmd-symposium-2019/3

This Article is brought to you for free and open access by the TMD Symposiums and Conferences at DigitalCommons@URI. It has been accepted for inclusion in Symposium: "Tales of North and South in Antebellum America: A Complicated Web" by an authorized administrator of DigitalCommons@URI. For more information, please contact digitalcommons-group@uri.edu. 


\title{
Patches of Resistance on the Badges of Enslavement
}

\author{
Katie Knowles \\ Colorado State University \\ September 28, 2019
}

The title of this paper is inspired by a line in Harriet Jacobs's autobiography Incidents in the Life of a Slave Girl (1861), when she states, "I have a vivid recollection of the linseywoolsey dress given me every winter by Mrs. Flint. How I hated it! It was one of the badges of slavery." Jacobs suggests that low quality fabrics such as linsey-woolsey, osnaburg, and negro cloth that were distributed to enslaved people for clothing identified their status as enslaved. Enslavers sought to reinforce racist categorizations of society by supplying limited, poor quality, and uniform textiles and clothing to enslaved people. This paper argues that the clothing choices made by enslaved people were a method of resistance against the racism, violence, and oppression of the slavery system in the antebellum United States. Sources, including a runaway advertisement for Jacobs, reveal a visualization of slavery that demonstrates the everyday wear of enslaved southerners in the antebellum period was highly individualized and comprised a multitude of fabrics, colors, and styles.

The oppositional uses of dress by enslavers and enslaved people are examined through the lens of recent scholarship on slavery studies, including work by Daina Ramey Berry (The Price for Their Pound of Flesh, 2017) and Marisa J. Fuentes (Dispossessed Lives, 2016). Their methodologies for archival research and their centering of enslaved people are used to consider evidence within the material archive of surviving clothing used by enslaved people. Artifacts examined in this paper include two aprons in the collection of the Charleston Museum and a skirt at the Smithsonian's National Museum of African American History and Culture.

These material and visual sources are used together with written and oral history sources to provide examples of how clothing functioned not only as a method of control and oppression, but also as a method of resistance. Enslavers created and enforced a race-based fashion system to dismiss enslaved peoples' efforts at collective and self-expression. Meanwhile, dress practices such as patching clothing with visible mending and styling unique ensembles became tools for resistance when enslaved people used them to throw off the "badge of slavery" as Harriet Jacobs called it, that came with the wearing of negro cloth. By insisting on their own fashionability, enslaved people struggled against a racist culture that attempted to exclude them as valid participants in and creators of American fashion culture.

Further questions and challenges are raised in this paper regarding the provenance of objects and the motivations surrounding efforts to preserve artifacts of slavery in the United States. In bringing together material culture studies and slavery studies scholarship, the paper prioritizes the lived experiences of enslaved people within the complex history of museums, preservation, and memory making. Direct links are made between the actions of enslavers and enslaved people in the use of dress to oppress and resist, and the actions of preservationists to reinforce or challenge the legacies of slavery.

\footnotetext{
${ }^{1}$ Harriet Jacobs, Incidents in the Life of a Slave Girl. Edited by Jean Fagan Yellin (1861, Cambridge: Harvard University Press, 2000), 11.
} 